\title{
House of Lords is asked to rule on breadth of gene patent coverage
}

London. Britain's House of Lords has been asked to adjudicate on an issue of key importance to the future of the biotechnology industry, namely the legitimate breadth of the patent claims that can be based on a particular genetic invention or 'discovery'.

At issue is the extent to which a company holding patent rights - for example, to part of a viral genome or to a key disease gene should be allowed to demand licences from other companies wishing to use related genetic information to develop diagnostic or therapeutic techniques. made on Monday by Biogen Inc., the US biotechnology company, after the Court of Appeal overturned its patent on recombinant DNA techniques for producing a vaccine against hepatitis $B$, in particular on the grounds that the claims made in the patent were too broad.

The patent described a technique - developed by Ken Murray of the University of Edinburgh - for producing hepatitis-B antigens by inserting DNA from the virus into an Escherichia coli vector. But it extended the claim to all similar techniques for producing antigens, whether for core or surface antigens, bacterial or non-bacterial hosts.

The court's ruling has come as a surprise to many patent lawyers, as it seems to conflict with the European Patent Convention. This states that the breadth of a patent cannot be challenged once it has been issued, an
The appeal to the House of Lords was

\section{Russians may lobby for science aid}

Washington. A group of Russian scientists is discussing ways of paying for a Washing ton lobbyist to boost efforts to persuade the Clinton administration to contribute money to the International Science Foundation (ISF), the research-funding agency set up by Hungarian-born financier George Soros.

The decision to employ a lobbyist was taken two weeks ago at a meeting of ISF grantees in Moscow. "If we do not receive more money, then funding for Russian scientists through the ISF will finish at the end of next year," says Vladimir Skulachev of Moscow University, the chairman of the ISF's Russian advisory committee.

Soros initially established the ISF with a gift of $\$ 100$ million, and later promised extra funding if this could be matched by other donors. In response, the Russian government has already promised to provide a further $\$ 12.5$ million, which Soros has agreed to match.

But despite lengthy negotiations with the State Department in Washington (including numerous requests from the US scientific interpretation recently confirmed by the appeals board of the Munich-based European Patent Office (EPO).

But the ruling was warmly welcomed by Medeva, the UK pharmaceutical company that challenged Biogen's patent. It had previously failed to block the application at the EPO, where Biogen obtained a patent on its hepatitis-B vaccine in July 1990.

Medeva is one of several companies seeking to challenge broad patents on the grounds that they give companies monopoly control over large fields of technology. The US

\section{IMAGE UNAVAILABLE FOR COPYRIGHT REASONS}

\section{Blood testing: who will control the technology?}

diagnostics company Murex International, will also be keen for any clarification of the issue that the House of Lords might provide. Its UK subsidiary, Murex Diagnostics, last week lost a further round in its worldwide challenge to the validity of a patent on a blood-screening test for hepatitis $\mathrm{C}$, held by

Chiron Corporation, the Californian biotechnology company that discovered the virus in 1987.

The court in London upheld an injunction requested by Chiron to stop Murex from continuing to make and sell hepatitis- $\mathrm{C}$ kits (Murex currently supplies around one-third of the British market). Murex lost a challenge to Chiron's patent last year, but wanted to continue producing kits until its appeal against this decision has been heard.

The new ruling has provoked widespread concern in the blood-testing research com-

$\vec{a}$ munity, partly because it prevents Murex - which does not hold a licence on Chiron's patent - from carrying out further research on screening techniques.

"It is not in the public interest for a company to be able to claim the whole area of a particular disease just because it has rights to a few sequences specific to the genetic material related to that disease," says Roger Williams, head of the Institute of Liver Studies at Kings College Medical and Dental School in London, and director of the Liver $\mathrm{Re}$ search Trust.

One concern of such critics is that only companies that license from Chiron - at present, Abbott Laboratories, Ortho and Pasteur - will have access to the UK market for hepatitis-C screening. They also point out that hepatitis-C tests cost three to four times more than other virus tests because of the royalty payments fixed by Chiron, said to be about $£ 1$ on a test that costs $50 \mathrm{p}$ to make.

Another is that Chiron's rights to the

community), the Clinton administration has so far refused to come up with any funding for the foundation.

The Russian scientists, who have pledged to provide the money out of their own pockets for a Washington lobbyist - as a nonprofit organization, the ISF is unable to engage in lobbying activities on its own behalf - are hoping that the foundation's future will be raised at a meeting in Moscow next week between US vice-president Al Gore and Russian Prime Minister Viktor Chernomyrdin.

The Russian science minister, Boris Saltykov, has already been approached to try to place the future of the ISF on the meeting's agenda. But, with many other issues already scheduled for discussion including US/Russian cooperation in space research - the prospects for this remain uncertain. As Roald Sagdeev of the University of Maryland's East-West Science and Technology Center, puts it: "The biggest problem for Russian science is not so much survival in the post-Soviet epoch, but survival in the post-Soros epoch."
hepatitis-C virus could eventually give it leverage over the key technologies used for blood screening worldwide. These are likely to be based on automated equipment that simultaneously screens for several viruses, including hepatitis $\mathrm{C}$, and Chiron's approval would therefore be required by any producer of such equipment.

"There is a general feeling in the blood transfusion service that, because of the way the technology is moving, the implications of this ruling are more serious than the issues raised by hepatitis-C screening alone," says one scientist who has been closely involved in developing novel screening techniques.

But officials at Chiron and its licensees deny that they are seeking to monopolize either research into techniques for hepatitis$\mathrm{C}$ screening, or the global blood-screening industry - the market for test kits is around $£ 200$ million (US\$314 million) a year. "Chiron has poured a lot of money into research in this area, which it is entitled to recoup," says John Menzies, sales director 


\section{of Ortho Diagnostic Systems.}

Mr Justice Aldous, the High Court judge responsible for the judgement, agreed. "Chiron's patent monopoly will in the short term deter some companies from carrying out research and development," he wrote. "But that is inherent in the patent system."

Aldous said he accepted that a patent holder's rights to restrict competition and put up prices was "contrary to the public interest". But he added that this was "the price that has been accepted to secure the advantages" that the patent system offers to inventors.

Indeed, the ruling against Murex - upholding Chiron's claim on future technologies for detecting hepatitis $\mathrm{C}$ conforms with recent decisions by the EPO to grant broad patents, for example on thermostable polymerases used in the polymerase chain reaction. But such rulings, as well as similar decisions in the field of agricultural genetics (see right) are coming under increasing fire both from the scientific community and from small companies.

There is a growing sentiment in the research community that broad patent claims on basic genetic discoveries may be creating an unacceptable hurdle to researchers seeking corporate sponsorship for their research, because companies may be unwilling to support research whose potential products are owned in advance by others.

Murex and other companies contesting broad patents on the grounds that they provide an unfair monopoly are turning to 'public interest' arguments to support their case. "The patent system has perhaps gone too far [in allowing broad patents]", says Peter Silverstone, director of business development at Murex Diagnostics. "Patents should protect something that is specific."

Chiron is quick to dispute charges that broad patents discourage research, as are others in the biotechnology industry, such as Genentech, Amgen, Eli Lilly, Hoffmann La-Roche and SmithKline Beecham. This is hardly surprising, given that their commercial success increasingly depends on being the first to patent key elements of knowhow, ranging from individual gene sequences to basic gene-sequencing technology, and subsequently exploit the market position that such patents allow.

If the House of Lords does review the Appeal Court's rejection of the Biogen patent, this will come too late to influence Murex's appeal, due to be heard next year, as the Lords hearing is unlikely to take place until 1996. But it would set an important precedent for the whole European bio-technology industry.

Furthermore, the House of Lords' views on gene patenting, which is already being considered separately by a select committee, are also likely to be closely examined in US circles, given for example the current debate there (see right) over 'reasonable pricing' clauses in joint industry/federal research projects.

David Dickson

\section{Soy-bean patent comes under fire as threat to research}

San Francisco. An international coalition of public-interest groups and the multinational company Monsanto have filed separate challenges to a broad European patent granted to an American biotechnology company on all genetic manipulation of soy-bean plants.

Both appeals have highlighted a mixture of concerns being expressed by activist groups, government agencies, researchers and sometimes other companies in the industry about the threat that broad patents may pose to research, the dangers of a monopoly over major food crops and the potential for loss of plant diversity.

Monsanto claims that the scientific data in the soy-bean application supported a patent of far narrower scope. Jim Altemus, spokesman for the chemical company, which is based in St Louis, Missouri, says the broad coverage of the patent may discourage others from entering the soy-bean area and carrying out original research not contained in the patent. "It's just too broad in coverage," says Altemus. "We're not objecting to patents per se."

The patent, issued by the European Patent Office on 2 March, means that any company or researcher interested in genetically engineering soy beans must arrange licensing from Agracetus Inc., a subsidiary of W. R. Grace \& Co. based in Middleton, Wisconsin.

Agracetus, which uses 'gene-gun' technology to move new genes into soy beans, won the broad claim on the grounds that its scientists were the first to show that the species could be genetically engineered by any method.

But the Rural Advancement Foundation International (RAFI), an Ottawa-based biotechnology watch-dog group that led the activist coalition's complaint, argues that the invention is neither novel nor 'nonobvious', as it is based on previous reported discoveries.

RAFI also says the patent is morally wrong because it would grant a single company a 17-year monopoly on genetic research on one of the world's most important food crops. Its challenge is intended to send a strong signal to the biotechnology industry - and to patent officials - that patenting major food crops is unacceptable, said Hope Shand, research director for RAFI-USA in North Carolina. She said the patent system was not designed for genetically engineered plants and other living things and is illequipped to handle them.

But Russell Smestad, vice president of finance and commercial development for Agracetus, argues that strong intellectual property rights have historically stimulated more active research and investment.

Agracetus has filed for a similar broadbased patent on soy-bean manipulation in the United States and Canada. It already holds a US patent for all transgenic cotton products, which is being re-examined by the US Patent Office following a challenge by the US Department of Agriculture and an anonymous party.

Sally Lehrman

\section{NIH 'should rethink pricing clause'}

Washington. The US National Institutes of Health (NIH) were urged last week by various members of their advisory councils to drop an unpopular clause that forms part of cooperative research agreements between industry and NIH intramural scientists.

The controversial clause allows the NIH to set "reasonable prices" for products developed jointly with industry. It was introduced following congressional and public anger over the cost of the antiAIDS drug AZT, which was partly developed in NIH laboratories.

Edmund Tramont, a member of the advisory council to the National Institute of Allergy and Infectious Diseases, last week told a meeting of the advisory committee to Harold Varmus, the director of NIH, that the Public Health Service is now sophisticated enough to guard against the unreasonable use of technology developed with public money. "I don't think the AZT case will arise again," he said.
Both David Guyton, an adviser to the National Eye Institute, and Timothy Wright, representing the National Institute for Dental Research, agreed. "The bottom line is that reas nable pricing clauses restrict cooperative research agreements," said Wright.

The NIH has spent much of the past year trying to decide what to do about such clauses. Many companies say they will not enter research agreements containing the clause because it discourages investment by venture capitalists.

Earlier this year, two ad hoc panels of NIH staff, extramural scientists and industrialists each agreed that something needs to be done about the clause as it now stands. But it remains unclear what the NIH, under pressure to revise the current clause but also to respect the need to protect public investment in research, will eventually recommend to the Public Health Service of the Department of Health and Human Services. 